Lewin, J. C. (1958). J. gen. Microbiol. 18, 427-432

\title{
The Taxonomic Position of Phaeodactylum tricornutum
}

\author{
BY JOYCE C. LEWIN \\ Woods Hole Oceanographic Institution, Woods Hole, Mass., U.S.A.
}

SUMMARY: A revised taxonomic description of Phaeodactylum tricornutum Bohlin is presented, with special emphasis on the details of the silica valve, a structure hitherto unobserved. The features distinguishing $\boldsymbol{P}$. tricornutum from Nitzschia closterium (Ehr.) W. Sm., with which it has frequently been confused, are summarized. In view of the unique characters of $P$. tricornutum, it is proposed to establish within the Bacillariales a new suborder, the Phaeodactylineae, to which Phaeodactylum is assigned as the only known genus.

In 1897 Bohlin described a new genus of unicellular algae, Phaeodactylum, with a single species, $\boldsymbol{P}$. tricornutum. The organism was stellate with three narrow arms, possessed yellow-brown chromatophores and was weakly silicified. On the basis of the chemical nature of the cells and their characteristic plane of division, parallel with that of the arms, Bohlin considered that $\boldsymbol{P}$. tricornutum was closely related to the diatoms. Wilson (1946), in a study of the various cell forms of 'Nitzschia closterium W. Sm. forma minutissima', recognized the triradiate form of this organism as identical with $P$. tricornutum Bohlin. Since Hendey (1954) found no evidence for siliceous structures in the cell walls of this organism, he felt that it could not be classed as a diatom, and the presence of leucosin, as shown by Parke (recorded by Hendey, 1954), suggested to him a possible relationship to the Chrysophyceae. On the basis of the absence of movement, the absence of a raphe, and the absence of siliceous structure, Bourrelly \& Drageseo (1955) also concluded that $P$. tricornutum could not be regarded as a diatom, but was a 'primitive Chrysococcalian'. Since the oval cells of $\boldsymbol{P}$. tricornutum have now been shown to possess a silica valve (Lewin, Lewin \& Philpott, 1958), it seems necessary to describe the organism more precisely on this basis, and to assign it to an appropriate taxonomic position. Though the specific epithet tricornutum might appear inappropriate, having been based on an atypical form, it has to be retained according to the rules of the International Code of Botanical Nomenclature (Lanjouw et al. 1956).

\section{NEW DESCRIPTION}

The emended description of the species is as follows:

Phaeodactylum tricornutum Bohlin emend.

Unicellular, normally with one parietal brown chromatophore in central region. Two typical forms of cells. (a) Ovate, $8 \mu$. long $\times 3 \mu$. wide, one silica valve per cell. Cells may be slowly motile, or immobile in mucilaginous clumps. $(b)$ Fusiform, up to $25-35 \mu$. long, with two more or less blunt, slightly bent arms. 
Silica wall absent. Non-motile. Rarely variants occur (triradiate, cruciform, lunate, etc.) which tend to persist in clones.

Valve weakly silicified, with a thin ragged margin; $6 \cdot 2 \mu$. long by $1 \cdot 6 \mu$. wide. Girdle bands absent. Valve flat, linear lanceolate, slightly curved, symmetrical about the transapical plane (as in Cymbella spp.); one edge convex, the other more or less straight with a median bulge. Ends broadly rounded but not capitate. Raphe slightly curved. Central area small, frequently with a pore on the side of the bulge. Striae approximately 60 (equivalent to 95 in $10 \mu$.), mostly transverse but radiating in region of bulge. Puncta 2-6 per stria. (These details are revealed by electron microscopy. Under the light microscope it is just possible to detect the axial area, but no other features of the valve can be distinguished.)

\section{CLASSIFICATION}

Phaeodactylum tricornutum should undoubtedly be assigned to the Chrysophyta, since the cells possess golden-brown chromatophores, store leucosin and oil, and develop a silica.wall at certain stages. The genus exhibits sufficient diatom characteristics to justify its inclusion within the class Bacillariophyceae. Among these features are the following: vegetative division longitudinal (usually not by formation of endospores), silica valve of a pennate diatom type, gliding movement of the oval cells, and auxospore formation.

The taxonomic position of Phaeodactylum tricornutum within the Bacillariophyceae is not readily apparent. Since the valve structure so closely resembles that of Cymbella spp. it might seem desirable to place the genus within the family Cymbellaceae. On the other hand, each oval cell possesses only one valve, and this feature distinguishes $P$. tricornutum from diatoms of all existing suborders. It is felt that this character, and the total absence of a siliceous wall from cells of the fusiform phase, provide sufficient justification for the formation of a new suborder. In the same way, various members of the Achnanthaceae, although their raphidate valves indicate close affinities to certain genera of the Biraphidineae, have been set apart as a separate suborder, the Monoraphidineae, on the basis of possessing dissimilar valves. It is therefore proposed that a new suborder, the Phaeodactylineae, be established. The taxonomic position of $\boldsymbol{P}$. tricornutum would then be as follows:
Phylum
Chrysophyta
Class
Bacillariophyceae
Order
Bacillariales (Hendey, 1937)
Suborder Phaeodactylineae (nov.subord.). Unlike all other diatoms hither- to described, the cells do not possess more than one silicified valve, which, when present, only partially covers the cell.
Cellulae valva unica, cellulam partim tegenti, instructae, vel nudae.

Family Phaeodactylaceae (nov.fam.).

Characteribus subordinis Phaeodactylineae.

The only family of the suborder. 
Genus Phaeodactylum (Bohlin, 1897). The only genus. Cells existing in two typical forms: motile oval cells which possess a silica valve, and non-motile fusiform cells lacking a silica valve.

Species P.tricornutum. The only known species. (Description p. 427.)

\section{Clarification of the distinctions between}

Phaeodactylum tricornutum Bohlin and Nitzschia closterium (Ehr.) W. Sm.

Over the past fifty years the organism known as 'Nitzschia closterium forma minutissima' has been widely used in investigations of various aspects of physiology and biochemistry of diatoms and for studies of marine plankton. It is obvious now that a most atypical diatom was selected. Phaeodactylum tricornutum is apparently not even a normal component of marine phyto-

Table 1. Comparative features of Nitzschia closterium (Ehr.) W. Sm. and Phaeodactylum tricornutum Bohlin

N. closterium

\begin{tabular}{|c|c|c|c|}
\hline \multirow[b]{3}{*}{ Length } & \multirow[t]{2}{*}{ N. closterium } & \multicolumn{2}{|c|}{ P. tricornutum } \\
\hline & & Fusiform cells & Oval cells \\
\hline & $\begin{array}{l}25-100 \mu . \text { (Cupp, } \\
\text { 1943) }\end{array}$ & Up to $25-35 \mu$. & $8 \mu$ \\
\hline Motility & Actively motile & Non-motile & Slowly motile \\
\hline Silica wall & $\begin{array}{l}\text { Two valves with ir- } \\
\text { regular markings. } \\
\text { Multiple, fraying in- } \\
\text { tercalary bands (see } \\
\text { Pl. 1, figs. } 2 \& 4 \text { ) }\end{array}$ & $\begin{array}{l}\text { None (see Pl. 1, } \\
\text { fig. 1). }\end{array}$ & $\begin{array}{l}\text { Single valve of Cym- } \\
\text { bella type. No } \\
\text { girdles or intercal- } \\
\text { ary bands (see Pl. 1, } \\
\text { fig. 3) }\end{array}$ \\
\hline Form of colonies & $\begin{array}{l}\text { Spreading rapidly } \\
\text { over surface in re- } \\
\text { ticulate pattern } \\
\text { with fimbriate } \\
\text { margin }\end{array}$ & $\begin{array}{l}\text { Rounded, margin } \\
\text { entire }\end{array}$ & $\begin{array}{l}\text { Spreading for short } \\
\text { distances, margin } \\
\text { irregular }\end{array}$ \\
\hline $\begin{array}{l}\text { Growth in liquid } \\
\text { media }\end{array}$ & $\begin{array}{l}\text { Cells settle and grow } \\
\text { in mucilaginous } \\
\text { masses }\end{array}$ & $\begin{array}{l}\text { Cells separate, tend } \\
\text { to remain suspended }\end{array}$ & $\begin{array}{l}\text { Cells settle and grow } \\
\text { in small mucilagi- } \\
\text { nous clumps }\end{array}$ \\
\hline $\begin{array}{l}\text { Heterotrophic } \\
\text { growth (in dark- } \\
\text { ness on } 0.5 \%, w / v \text {, } \\
\text { glucose) }\end{array}$ & $\begin{array}{l}\text { Yes ( } 3 \text { isolates tested) } \\
\text { (Lewin, unpublished) }\end{array}$ & No (3 isola & tes tested) \\
\hline
\end{tabular}

plankton, since it has usually been reported from intertidal rock-pools or seawater tanks. It therefore seems unjustifiable to extend conclusions drawn from studies with this alga to diatoms in general or to phytoplankton. As a further complication, physiologists using the Plymouth strain often dropped the designation 'forma minutissima', and referred to it in publications simply as ' $N$. closterium'. Since a true $N$. closterium exists, which is very different from $\boldsymbol{P}$. tricornutum (see Table 1 ), it is often difficult to be sure which of the two organisms was being studied. As far as can be determined, the Plymouth strain of ' $N$. closterium f. minutissima' was the subject of investigation in the following papers: Ahmad (1930); Barker (1935); Bidwell, Krotkov \& Reed (1952); Chu (1946a, b); Clarke \& Mazur (1941); Dutton \& 
Manning (1941); Dutton, Manning \& Duggar (1943); French (1955); Harvey (1933, 1937, 1953 $a, b)$; Hutner (1948); Jameson, Drummond \& Coward (1922); Ketchum (1939 $a, b)$; Ketchum, Lillick \& Redfield (1949); Ketchum \& Redfield (1938, 1949); King \& Davidson (1933); Leigh-Clare (1927); Levring (1945); Lovern (1936); Lucas (1936); Pace (1941); Peach \& Drummond (1924); Spencer (1952, 1954); Stanbury (1931); Strain \& Manning (1942); Waksman, Stokes \& Butler (1937); Villeret (1955); von Brand, Rakestraw \& Renn (1937, 1939); von Brand \& Rakestraw (1940); ZoBell (1935). In 1954, Ryther isolated another strain of $\boldsymbol{P}$. tricornutum from the Great South Bay, Long Island, N.Y., which likewise was referred to as ' $N$. closterium' in the following papers: Ryther (1954, 1956a, b); Ryther \& Vaccaro (1954). Riley (1943) obtained a crude culture of ' $N$. closterium' from a tank containing sea water from Long Island Sound enriched with commercial fertilizer. The cells had the same dimensions as $\boldsymbol{P}$. tricornutum and, as in $\boldsymbol{P}$. tricornutum, dense cultures could be grown without added silicate. Unfortunately, since the culture has been lost, it is no longer possible to determine its identity. The information contained in all of the papers listed above, with the possible exception of Riley (1943), should in the future be considered as relating to P. tricornutum.

Contribution No. 936 from the Woods Hole Oceanographic Institution, Woods Hole, Massachusetts. These studies were supported by Contract NR-163-392 between the Biology Branch, Office of Naval Research, and the Woods Hole Oceanographic Institution. The author is indebted to Mr N. I. Hendey (Admiralty Materials Laboratory), Mr R. Ross (British Museum), Dr G. Papenfuss (University of California), Dr P. Conger (Smithsonian Institution, Washington), Dr W. R. Taylor (University of Michigan), and Dr H. Bold (University of Texas) for valuable guidance with problems of taxonomy. The electron micrographs were taken in collaboration with Mr D. E. Philpott, Marine Biological Laboratory, Woods Hole, Mass.

\section{REFERENCES}

Ahmad, B. (1930). Observations on a diatom (Nitzschia closterium W. Sm.) as a source of vitamin A. Biochem. J. 24, 860.

Barker, H. A. (1935). Photosynthesis in diatoms. Arch. Mikrobiol. 6, 141.

Bidwell, R. G. S., Krotkov, G. \& Reed, G. B. (1952). Paper chromatography of sugars in plants. Canad. J. Bot. 30, 291.

BoHIIN, K. (1897). Zur Morphologie und Biologie einzelliger Algen. Öfvers. VetenskAkad. Förh., Stockh. 54, 507.

Bourrelly, P. \& Dragesco, J. (1955). Contribution à la conaissance d'une algue rarissime 'Phaeodactylum tricornutum' Bohlin. Bull. Micr. Appl. (2), 5,41 .

Brand, T. von \& Rakestraw, N. W. (1940). Decomposition and regeneration of nitrogenous organic matter in sea water. III. Influence of temperature and source and condition of water. Biol. Bull., Woods Hole, 79, 231.

Brand, T. von, Rakestraw, N. W. \& Renn, C. E. (1937). The experimental decomposition and regeneration of nitrogenous organic matter in sea water. Biol Bull., Woods Hole, 72, 165.

Brand, T. von, Rakestraw, N. W. \& Renn, C. E. (1939). Further experiments on the decomposition and regeneration of nitrogenous organic matter in sea water. Biol. Bull., Woods Hole, 77, 285. 
CHU, S. P. (1946a). The utilization of organic phosphorus by phytoplankton. J. mar. biol. Ass. U.K. 26, 285.

CHU, S. P. (1946b). Note on the technique of making bacteria-free cultures of marine diatoms. J. mar. biol. Ass. U.K. 26, 296.

Clarke, H. T. \& Mazur, A. (1941). The lipids of diatoms. J. biol. Chem. 141, 283.

Cupp, E. E. (1943). Marine plankton diatoms of the west coast of North America. Bull. Scripps Instn Oceanogr. 5, (1) 1.

Dutton, H. J. \& Manning, W. M. (1941). Evidence for carotinoid-sensitized photosynthesis in the diatom Nitzschia closterium. Amer. J. Bot. 28, 516.

Dutton, H. J., Manning, W. M. \& Duggar, B. M. (1943). Chlorophyll fluorescence and energy transfer in the diatom Nitzschia closterium. J. phys. Chem. 47, 308.

French, C. S. (1955). Fluorescence spectrophotometry of photosynthetic pigments. In The Luminescence of Biological Systems, pp. 51-74. Editor Frank H. Johnson. Washington, D.C.: A.A.A.S.

Harvey, H. W. (1933). On the rate of diatom growth. J. mar. biol. Ass. U.K. 19, 253.

Harvey, H. W. (1937). The supply of iron to diatoms. J. mar. biol. Ass. U.K. 22, 205.

HaRveY, H. W. $(1953 a)$. Synthesis of organic nitrogen and chlorophyll by Nitzschia closterium. J. mar. biol. Ass. U.K. 31, $47 \%$.

Harvey, H. W. (1953b). Note on the absorption of organic phosphorus compounds by Nitzschia closterium in the dark. J. mar. biol. Ass. U.K. 31, 475.

Hendey, N. I. (1937). The plankton diatoms of the Southern Seas. 'Discovery' Rep. 16, 151.

Hendey, N. I. (1954). Note on the Plymouth 'Nitzschia' culture. J. mar. biol. Ass. U.K. 33, 335.

HutNer, S. H. (1948). Essentiality of constituents of sea water for growth of a marine diatom (N. closterium). Trans. N.Y. Acad. Sci. 10, 136.

Jameson, H. L., Drummond, J. C. \& Coward, K. H. (1922). Synthesis of vitamin A by a marine diatom (Nitzschia closterium W. Sm.) growing in pure culture. Biochem. J. 16, 482.

Kетсним, B. H. (1939a). The absorption of phosphate and nitrate by illuminated cultures of Nitzschia closterium. Amer. J. Bot. 26, 399.

Keтchum, B. H. $(1939 b)$. The development and restoration of deficiencies in the phosphorus and nitrogen composition of unicellular plants. J.cell.comp. Physiol. 13, 373.

Ketchum, B. H., Lillick, L. \& Redfield, A. C. (1949). The growth and optimum yields of unicellular algae in mass culture. J. cell. comp. Physiol. 33, 267.

Ketchum, B. H. \& Redfield, A. C. (1938). A method for maintaining a continuous supply of marine diatoms by culture. Biol. Bull., Woods Hole, 75, 165.

Ketchum, B. H. \& Redfield, A. C. (1949). Some physical and chemical characteristics of algae growth in mass culture. J. cell. comp. Physiol. 33, 281.

KING, E. J. \& DAvidson, V. (1933). IV. Relation of silica to the growth of phytoplankton. Biochem. J. 27, 1015.

Lanjouw, J. et al., editors (1956). International Code of Botanical Nomenclature. Utrecht, Netherlands.

LEIGH-Clare, J. L. (1927). A search for vitamin D in the diatom Nitzschia closterium (W. Sm.). Biochem. J. 21, 368.

Levring, T. (1945). Some culture experiments with marine plankton diatoms. Göteborgs VetenskSamh. Handl. F. 6, Ser. B, 3, no. 12, 1.

Lewin, J. C., Lewin, R. A. \& Philpott, D. E. (1958). Observations on Phaeodactylum tricornutum. J. gen. Microbiol. 18, 418.

Lovern, J. A. (1936). Fat metabolism in fishes. IX. The fats of some aquatic plants. Biochem. J. 30, 387.

LuCAS, C. E. (1936). On certain inter-relations between phytoplankton and zooplankton under experimental conditions. J. Cons. int. Explor. Mer, 11, 343. 
PaCe, N. (1941). Pigments of the marine diatom Nitzschia closterium. J. biol. Chem. 140, 483.

Peach, E. A. \& Drummond, J. C. (1924). On the culture of the marine diatom Nitzschia closterium (f.) minutissima in artificial sea water. Biochem. J. 18, 464.

Riley, G. A. (1943). Physiological aspects of spring diatom flowerings. Bull. Bingham oceanogr. Coll. 8, (Art. 4), 1.

Ryther, J. H. (1954). The ecology of phytoplankton blooms in Moriches Bay and Great South Bay, Long Island, New York. Biol. Bull., Woods Hole, 106, 198.

Ryther, J. H. (1956a). Photosynthesis in the ocean as a function of light intensity. Limnol. and Oceanogr. 1, 61.

RYTher, J. H. (1956b). The measurement of primary production. Limnol. and Oceanogr. 1, 72.

RYther, J. H. \& Vaccaro, R. F. (1954). A comparison of the oxygen and $\mathrm{C}^{14}$ methods of measuring marine photosynthesis. J. Cons. int. Explor. Mer, 20, 25.

Spencer, C. P. (1952). On the use of antibiotics for isolating bacteria-free cultures of marine phytoplankton organisms. J. mar. biol. Ass. U.K. 31, 97.

Spencer, C. P. (1954). Studies on the culture of a marine diatom. J. mar. biol. Ass. U.K. 33, 265.

Stanbury, F. A. (1931). The effect of light of different intensities, reduced selectively and non-selectively, upon the rate of growth of Nitzschia closterium. J. mar. biol. Ass. U.K. 17, 633.

Strain, H. H. \& Manning, W. M. (1942). Chlorofucine (chlorophyll $\gamma$ ), a green pigment of diatoms and brown algae. J. biol. Chem. 144, 625 .

Villeret, S. (1955). Sur la présence des enzymes des uréîdes glyoxyliques chez les algues d'eau douce. C.R. Acad. Sci., Paris, 241, 90.

Waksman, S. A., Stokes, J. L. \& Butler, M. R. (1937). Relation of bacteria to diatoms in sea water. J. mar. biol. Ass. U.K. 23, 359.

Witson, D. P. (1946). The triradiate and other forms of Nitzschia closterium (Ehrenberg) Wm. Smith, forma minutissima of Allen and Nelson. J. mar. biol. Ass. U.K. 26, 235.

ZoBeLL, C. E. (1935) The assimilation of ammonium nitrogen by Nitzschia closterium and other marine phytoplankton. Proc. nat. Acad. Sci., Wash. 21, 517.

\section{EXPLANATION OF PLATE}

Electron micrographs. Each scale line represents $2 \mu$.

Fig. 1. Fusiform cells of Phaeodactylum tricornutum Bohlin.

Fig. 2. Silica wall of Nitzschia closterium (Ehr.) W. Sm.

Fig. 3. Silica walls of oval cells of $P$. tricornutum.

Fig. 4. Enlarged portion of silica wall of $N$. closterium. 
Journal of General Microbiology, Vol. 18, No. 2

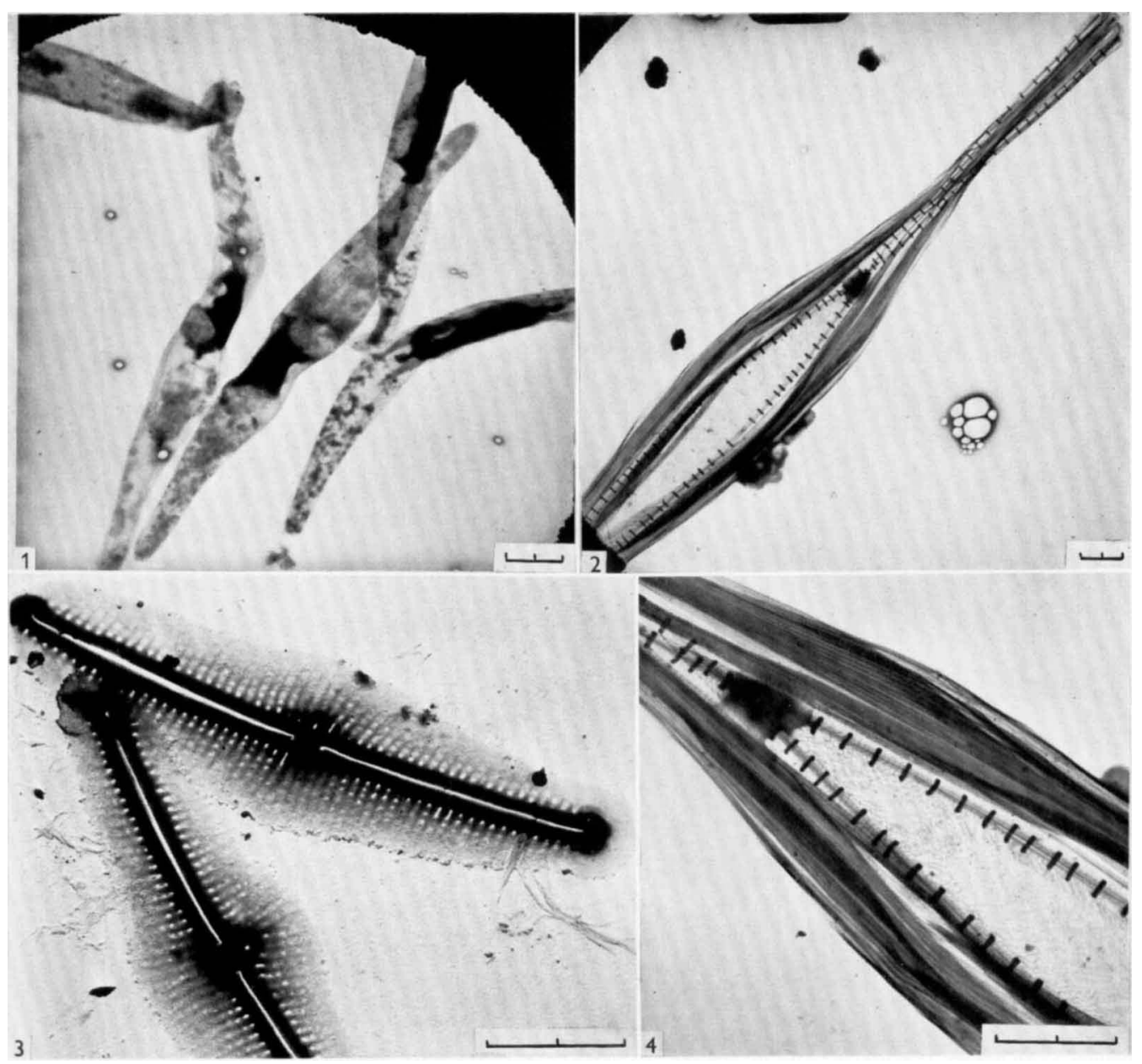

J. C. Lewin--The taxonomy of Phabodactylum tricorvetym. Plate 1

(Facing p. 432) 